\title{
Specialization of Emerging Countries and Economic Stability ${ }^{1}$
}

\author{
Dr. Ons Abbes \\ University of Paris-Est Creteil and University of Tunis el Manar \\ 61 Avenue of Général de Gaulle, 94000 Créteil, France \\ University Campus Farhat Hached, B.P. n 94 - Rommana, Tunisia \\ E-mail: abbes.ons2@gmail.com
}

\begin{abstract}
Pr. Abdessatar Ati (Corresponding author)
JCBA, Jazan University, KSA. FSJEG Jendouba, Jendoua University, Tunisia

E-mail: atiabdessatar@yahoo.fr
\end{abstract}

Dr. Fabienne Boudier

University of Paris-Est Créteil

61 Avenue of Général de Gaulle, 94000 Créteil, France

Received: December 30, 2018 Accepted: January 12, 2019 Published: March 1, 2019

doi:10.5296/ber.v9i1.14445 URL: https://doi.org/10.5296/ber.v9i1.14445

\begin{abstract}
The Emerging countries are characterized by high vulnerability. Their development process is therefore likely to be severely hampered by shocks, contributing to high volatility in their economic growth. To understand the high vulnerability of emerging countries, we explore the impact of structure and degree of specialization on economic instability. We find that countries whose specialization is based on natural resources are more unstable. On the other hand, increased research and development spending and a high number of patent applications reduce this instability. We also note that the impact of specialization in high technology depends on the level of development of the country; it is positive in emerging countries and
\end{abstract}

\footnotetext{
${ }^{1}$ In memory of Fabienne Boudier
} 
negative in developed countries. This difference in the sign of the impact can be explained by a difference in the origin of the technology incorporated into the exports in these two categories of countries.

We can conclude, then that the vulnerability of emerging countries and partly due to their specialization policies which are oriented mainly to products that come from natural resources and gathering of high-tech items.

Keywords: Economic stability, Emerging country, Growth, Vulnerability

\section{Introduction}

The International trade has grown strongly in recent decades. The costs of this increased growth are often discussed in the literature on international economics, particularly the contribution of foreign trade to macroeconomic instability (e.g., Di Giovanni and Levchenko, 2009, 2010, Rodrik, 1998).

Macroeconomic instability is considered by several authors (e.g., Dawe 1996, Dehn 2000, Guillaumont et al., 1999, Hnatkovska and Loayza 2005) as a major impediment to growth. However, some studies (including Hnatkovska and Loayza 2004, Imbs 2007, Rancière et al., 2008) show that, under certain conditions, instability can have a positive impact on growth.

Instability, manifested by large and sometimes abrupt movements in economic variables (Plihon, 2008), is often explained by the relationship between country ry and low-amplitude fluctuations of economic variables around their average value (Plihon, 2008).

In a founding article, Lucas (1988) found that in the long terspecialization, level of development, and volatility. The latter describes the temporam, the fluctuations in growth rates are likely to be larger in less developed countries than in developed countries. This relationship is illustrated in Figure 1, which links the standard deviation of the annual per capita growth rate with the level of real GDP per capita for a large selection of countries.

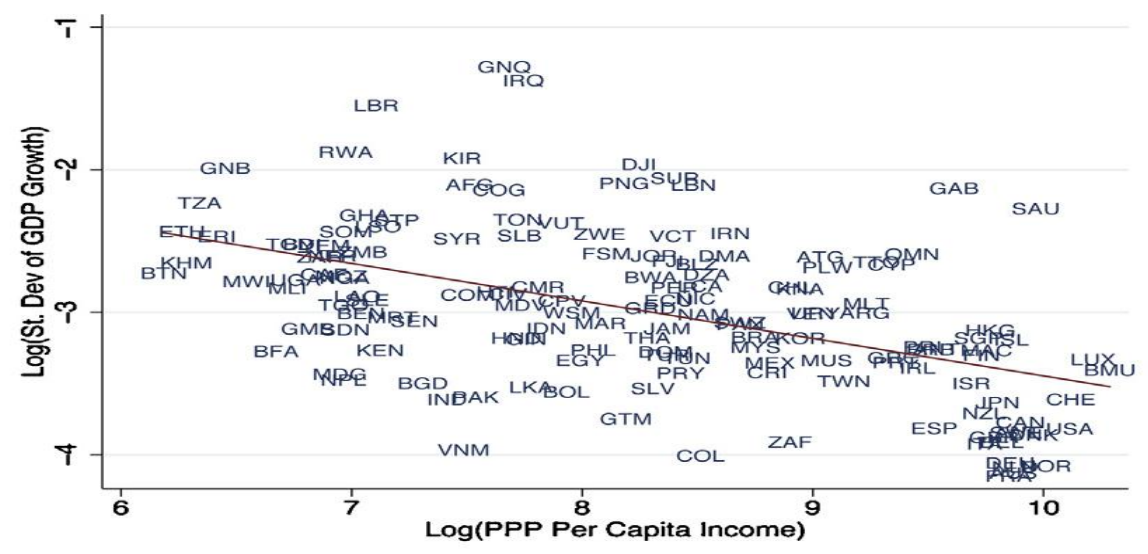

Figure 1. Relation between the standard deviation of the annual per capita growth rate and the level of real GDP per capita, 1960-1997

Source: Penn world tables and UNIDO in Levchenko and Krishna (2012) page 315. 
According to Azeinman and Pinto (2005), Hnatkovska and Loayza (2004), Koren and Tenreyro (2007), Krishna and Levchenko (2009), Loayza et al. (2007) and Tapia (2012), this risk of fluctuation is greater in developing countries than in developed countries given their specializations in risky sectors (see point 1.2). Thus, countries that have specialized in particularly risky sectors will face a significant risk of macroeconomic volatility.

This article is organized as follows: The first section presents a review of the literature on the sources of vulnerability that leads countries to instability and crisis, with a focus on the relationship between specialization and volatility; the second section examines the macroeconomic instability, crises and specialization of emerging countries and the third section empirically tests the impact of the specialization of emerging countries on economic instability and compares this impact with that of developed countries. The last part concluded.

\section{Review of the Literature}

Studying the impact of the specialization of emerging countries on their economic instability leads us to focus on two parts of the literature, namely the sources of vulnerability in general and the relationship between specialization in risky sectors and volatility.

\subsection{The Sources of Vulnerability of Countries}

Macroeconomic vulnerability is analyzed as the risk of being affected by shocks that are a handicap for development and growth. According to Raddatz (2007) and Cariolle (2012), these shocks can be internal (agricultural production, economic policy, environmental and climatic disasters) or external (decrease in external demand, instability of world prices of commodities fluctuations in the terms of trade). In their studies Hnatkovska and Loayza (2005) and Rancière et al. (2008), classify shocks as exogenous (international trade, environmental disasters) and endogenous (economic policy). We can distinguish the structural vulnerability, which results from exogenous factors that are permanently independent of the political will of the countries, from the vulnerability stemming from endogenous factors.

Several authors (including Cariolle 2011, Combes and Guillaumont 2002, Guillaumont 2007, 2009, 2010, Loayza and Raddatz 2007), show that external and natural shocks (environmental and climatic disasters) play an important role in vulnerability within developing countries. Unlike these authors, Raddatz (2007) finds that, although these shocks are often blamed for countries' poor economic performance, they can only explain a small fraction of their volatility. On the other hand, internal shocks (in particular, economic policy) are the main source of fluctuations. These results confirm those of Fatas and Mihov (2006, 2007), which show that economic volatility results largely from the instability of fiscal policy.

Mauro and Becker (2006) contradict Raddatz (2007) and confirm the results found by Cariolle (2011), Guillaumont (2007, 2009, 2010) and Loayza and Raddatz (2007). According to Mauro and Becker (2006), the impact of external shocks on instability is very important. These authors also add that the costs of these shocks depend on the characteristics of the country. For emerging countries, the highest costs are associated with external financial 
shocks (such as sudden stops in financial flows) and for developing countries, the highest cost corresponds to actual external shocks (especially in terms of trade). Koren and Tenreyro (2007) also show that vulnerability to risk depends on country characteristics. To explain the variation in risk vulnerability between poor and rich countries, these authors find that poor countries are more volatile for three reasons:

1) Specialization in few sectors (low diversification) ${ }^{2}$ and in volatile sectors;

2) Very frequent and very severe global shocks in these countries (e.g. shocks related to their economic policies);

3) The macroeconomic fluctuations of poor countries strongly correlated with the shocks affecting the sectors in which they specialize.

Following these results, Koren and Tenreyro (2007) identify three components of the volatility of overall GDP growth. The first concerns the volatility of sectoral shocks (an economy that specializes in risky sectors will tend to experience higher overall volatility). The second component concerns national shocks (some countries are subject to greater political instability). The third component relates to the covariance between sector-specific and country-specific shocks: for example, fiscal innovation or monetary policy in some countries may be related to sector-specific shocks.

In our research, we focus on the first component of volatility (volatility of sectoral shocks). According to the literature (Azeinman and Pinto, 2005, Hnatkovska and Loayza, 2004, Koren and Tenreyro, 2007, Krishna and Levchenko, 2009, Loayza et al., 2007 and Tapia, 2012), the degree and areas of specialization were often used to explain the relationship between openness and volatility. However, we note that the definition and measurement of a sector at risk differs from one author to another. For some, a sector at risk is a sector that contains low-complexity products and for others, it is a sector that is intensive in raw materials or that uses traditional technologies.

The degree of specialization that can be measured by the degree of concentration of exports is an important factor in amplifying the transmission effects of the crisis. According to Massell (1964); Neto and Romeu (2011) and Rose and Spiegel (2011), there is a positive relationship between the volatility of export earnings and the concentration of exports. In other studies, Costa Neto and Romeu (2011), based on the example of Latin America and Cheewatrakoolpong and Manprasert (2015), based on the example of Thailand found that the concentration of exports significantly increases the degree of collapse of trade during a crisis.

According to Meilak (2008), the two most commonly used concentration measures in the literature are the Herfindahl Index and the Hirschman Index ${ }^{3}$. Meilak (2008) explains that the Herfindahl Index is the simplest and easiest to use. Therefore, and following Neto and Romeu

\footnotetext{
${ }^{2}$ Koren and Tenreyro (2007) support the results found by Acemoglu and Zilibotti (1997), which show that opportunities for diversification in developing countries are limited because of the scarcity of capital and the indivisibility of investment projects.

${ }^{3}$ The Hirschman index is very similar to the Herfindahl index. It is, in fact, the square root of the Herfindahl index.
} 
(2011) and Cheewatrakoolpong and Manprasert (2015), we use the Herfindahl index to measure the concentration of export sectors.

This index has been normalized to obtain classification values between 0 and 1 (maximum concentration), according to the following formula:

$H_{j}=\frac{\sqrt{\sum_{i=1}^{n}\left(\frac{x_{M}}{x}\right)^{2}-\sqrt{1 / n}}}{1-\sqrt{1 / n}}$

Where $\mathrm{Hj}$ is the index of the country or group of countries and $\mathrm{xi}$, the export of the product $\mathrm{i}$

$X=\sum_{i=1}^{n} x_{i}$

Where $\mathrm{n}$ is the number of products

Based on the literature, we will study the sectors at risk as following.

\subsection{Risk Sectors and Volatility}

The risk areas we are looking at are the natural resource-based and the low technology sectors.

\subsubsection{Volatility and Natural Resources}

According to Hausmann et al., (2004), Sachs and Warner (1997, 2001), the most unstable countries are undiversified economies and benefit mainly from endowments of natural resources. This result has been confirmed by Blattman et al., (2007). Their study of the growth performance of 35 countries during the historical period from 1870 to 1939 led to the following conclusions: countries that specialize in unstable price products experience greater volatility in their terms of trade and benefit less from foreign direct investment and vice versa for countries that specialize in products with more stable prices. However, Ding and Field (2005), Brunnschweiler and Bulte (2008), contradict this traditional interpretation of the curse of natural resources. These authors found that by using resource abundance (measured by natural resource wealth stocks) rather than dependence (measured by natural resource exports as a percentage of GDP) as an explanatory variable of resources, we obtain a positive and meaningful relationship with the growth of resources. By following these authors, Van der Ploeg and Poelhekke (2009) found that the direct effect of natural resources on growth could be positive. However, over the long term and using the indirect effect of natural resources on growth via the volatility channel, the impact is negative. Ploeg and Poelhekke (2009) have shown that this resource curse is primarily a problem of volatility. Indeed, the high volatility of world prices of natural resources leads to high volatility of GDP per capita growth in resource-rich countries. This volatility in output growth has a negative effect on long-term growth. 


\section{Measurement of endowments of natural resources}

In most studies, specialization in natural resources is measured by the share of natural resource exports in GDP. According to Guttmann and Richards (2006), the problem with this measure is that, on the one hand, the share of exports in GDP varies greatly with the size of the country, so that a large country, such as Brazil, can have a relatively high ratio of natural resources in exports $(45 \% \text {, compared to } 85 \% \text { in Chile })^{4}$, but a relatively low ratio of these exports to GDP (4\%, compared with $19 \%$ in Chile). On the other hand, the adverse effects of specialization in resources depend on their proportion to GDP rather than their proportion to exports (e.g. the impact of rents on fiscal policy). With this line of reasoning, Bleaney and Halland (2014) use natural resource exports as a proportion of total exports when the dependent variable in the regression is growth and use natural resource exports as a proportion of total exports. GDP when the dependent variable is a measure of volatility.

Natural resource endowments can also be measured using the specialization index in labor-intensive and natural resource-based manufactured items (see Annexes 1 and 2). This measure allows the use of natural resource exports as a proportion of total exports and as a proportion of GDP.

\subsubsection{Volatility and Innovation}

According to several authors, including Koren and Tenreyro (2007) and Tapia (2012), economic cycles are both less volatile and more synchronized with the global cycle in rich countries than in poor countries. To explain these volatility differentials, Kraay and Ventura (2006) develop the explanation that rich countries specialize in industries that use new technologies exploited by skilled workers, while poor countries specialize in industries that use traditional technologies exploited by unskilled workers.

Since each sector responds differently to shocks, the structure of a country's specialization can be a source of stability or economic instability. For example, sectors using new technologies benefit from demand for more elastic products than sectors using traditional technologies. Indeed, new technologies are difficult to imitate quickly for technical reasons and because of legal patents. This imitation difficulty gives developed countries monopoly power in the world markets. Traditional technologies, on the other hand, are easier to imitate because enough time has elapsed since their adoption and also because patents have expired or been bypassed (Tapia, 2012). This implies that firms in developing countries face strong competition from potential new competitors and have little or no monopoly power in global markets.

The incomes of industries using new technologies are likely to be less sensitive to country-specific shocks than those of industries using traditional technologies.

\section{Measure of innovation}

Innovation is measured by proxies since there is no direct measurement. According to the literature (Anderton 1999, Ang et al., 2015, Carlin et al., 2001, Crepon et al., 1998,

${ }^{4}$ Calculations by Guttmann and Richards (2006) based on WDI data for 2006. 


\section{Macrothink}

Fagerberg1988, Fagerberg 1997, Greenhalgh 1990, Greenhalgh et al. 1979, Magnier and Toujas-Bernate, 1994) innovation is often measured using two types of measures: inputs and outputs. Inputs, that is, all that is injected into the innovation system, will encompass variables such as the funding of Research and Development (R \& D) or the number of researchers while the outputs include scientific publications or the patents filed. In empirical studies, the two variables most often used to measure innovation, because of their availability, are R \& D expenditures and patents filed (Fagerberg, 1988). Innovation can also be measured using the degree of specialization in high-tech manufactures (see Annexes 1 and 2).

\section{Macroeconomic Instability, Crises and Specialization of Emerging Countries}

In this section, we will first study the instability and crises experienced by emerging countries by comparing them with those of the developed countries. Then, we analyze the structure and degree of specialization of these countries.

\subsection{Macroeconomic Instability and Crises in Emerging Countries}

\subsubsection{Macroeconomic Instability}

To compare economic instability in emerging ${ }^{5}$ and developed countries ${ }^{6}$, we calculated the growth rate and standard deviation of real GDP (see figure 2 and 3).

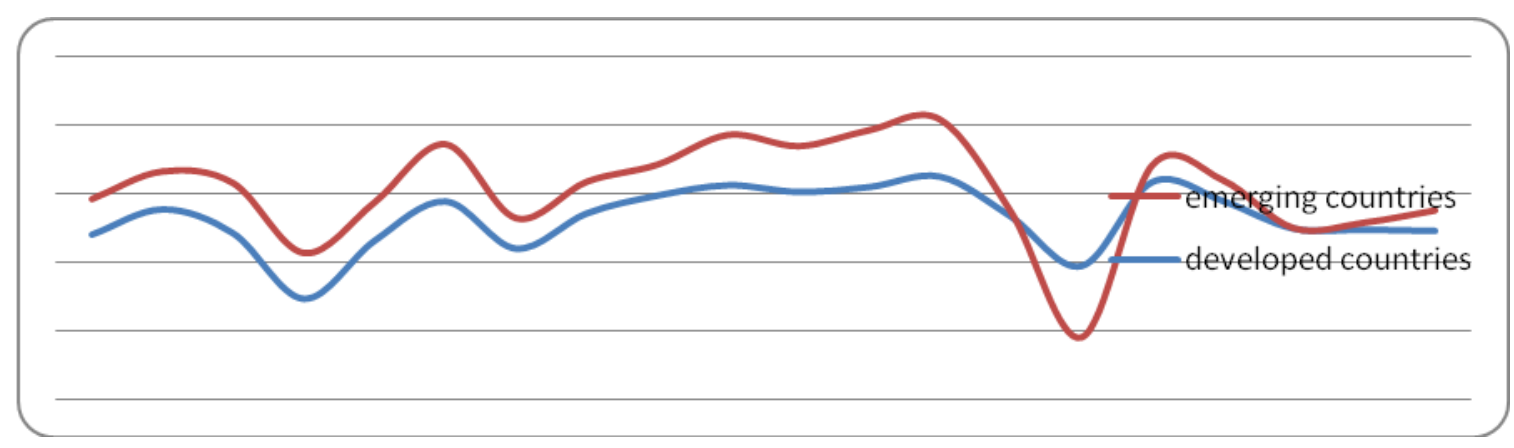

Figure 2. Real GDP growth rate of emerging and developed countries, 1995-2014, percentage

Source: author according to WDI.

The graph illustrates the two most important crises that have marked the last two decades: the Asian crisis and the subprime crisis. Regarding the first crisis, the emerging countries were the most affected with a decrease in growth in 1997 of $127 \%$ against $38 \%$ in developed countries $^{7}$.

This crisis was triggered in Thailand in 1996. Among the causes, can be put forward in the first place a poor domestic allocation of foreign resources borrowed mainly in dollars. This debt in foreign currency is mainly explained by the application of fixed exchange rates which gave a false sense of security to borrowers. Second, in 1997, Thai exports declined for a

\footnotetext{
${ }^{5}$ See Annex 3 for the list of emerging countries.

${ }^{6}$ According to the UN classification.

${ }^{7}$ Author's calculations based on WDI data.
} 


\section{Macrothink}

Business and Economic Research

ISSN 2162-4860

2019, Vol. 9, No. 1

number of reasons, including the loss of some markets with the entry into force of the North American Free Trade Agreement (NAFTA).

Due to a lack of currency to support its currency against the Dollar, the Thai was forced to float the baht hence the financial collapse of its currency.

This crisis has spread to most countries in Southeast Asia. Indonesia, South Korea and Thailand were the country most affected by the crisis. Hong Kong, Laos, Japan, Malaysia and the Philippines were also hurt by the fall. Brunei, China, Singapore, Taiwan and Vietnam were less affected.

During the subprime crisis that began in the United States, the developed countries were the most affected with a decline in growth in 2008 of $113 \%{ }^{8}$ in developed countries against $80 \%$ ${ }^{9}$ in emerging countries.

This crisis has penalized emerging countries over a short period (between 2008 and 2009). After this period, a clear recovery in growth was noted. The emerging countries of Asia and Latin America have been able to cope with this crisis thanks to lessons learned from past crises. These countries are now less exposed to risks thanks to their rather accommodating financial and economic environment (debt in foreign currency and foreign exchange reserves are more controlled, banking sectors and public finances are better structured, etc.).

However, we note that in recent years and more specifically from 2012, the growth of emerging countries has decreased. This decrease was $35 \%{ }^{10}$ in 2012.

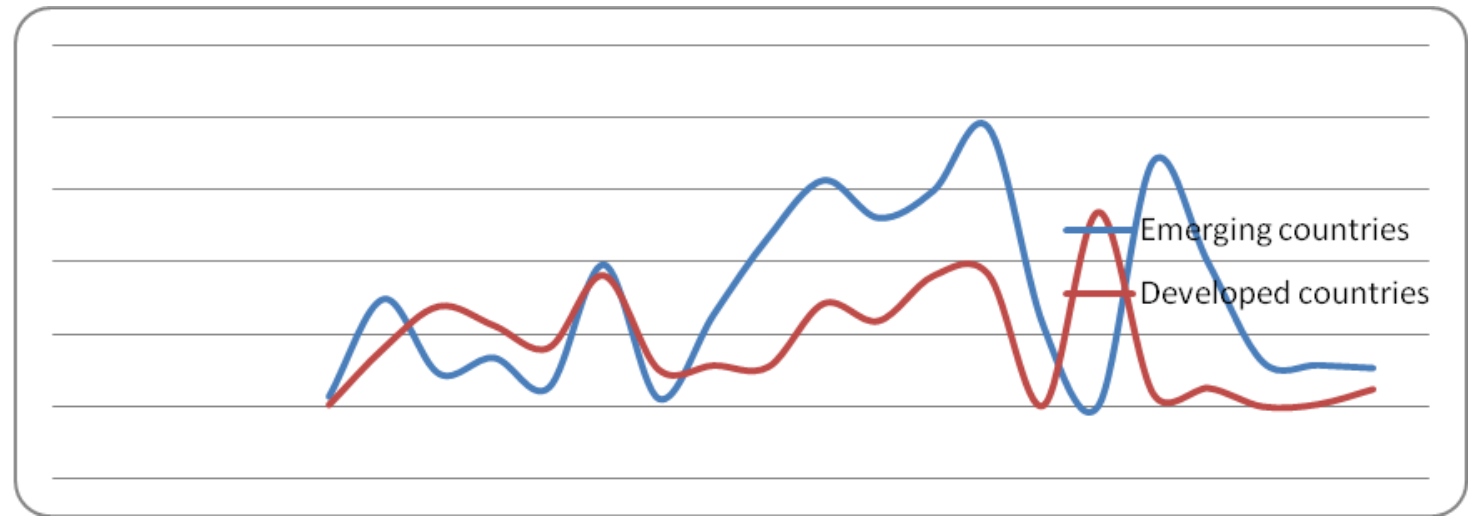

Figure 3.Standard deviation of real GDP of emerging and developed countries, 1995-2014

Source: author according to WDI.

Emerging countries are characterized by greater vulnerability compared to developed countries. Growth in emerging countries may be hindered by natural, political, social and economic shocks. These shocks can affect their supply (for example, climate shocks) or

\footnotetext{
${ }^{8}$ Author's calculations based on WDI data.

${ }^{9}$ Author's calculations based on WDI data.

${ }^{10}$ Author's calculations based on WDI data.
} 
demand for their products (for example, the change in global demand), which contributes to high volatility in their economic growth (Guillaumont, 2006).

The impact of the various shocks on the country's instability depends on the country's structural characteristics (geographic location, endowment of natural resources, etc.) and its economic policy. This variation in the impact of shocks can be seen in Figure 4, which illustrates the change in the growth rate in the different emerging countries.

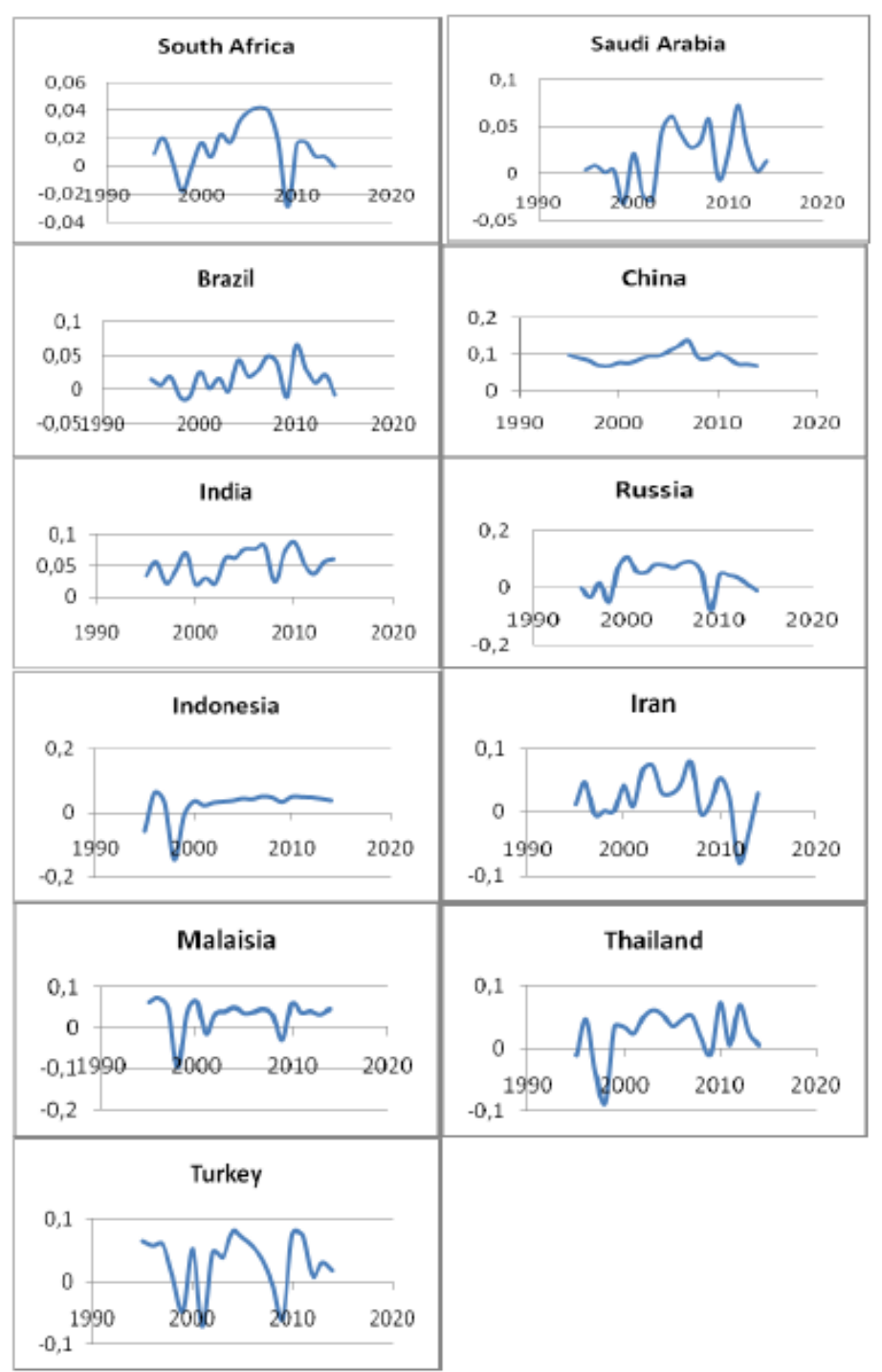

Figure 4. GDP growth rate of different emerging countries, 1995-2014, percentage

Source: Author's calculations from WDI

Figure 4 shows that these countries have gone through cycles of expansion and recession. The highest volatility of the cycles was recorded during the Asian crisis of 1997 and during the subprime crisis. Based on the degree to which countries have been affected by these two crises, we can classify our sample into three groups. A country is considered to be strongly affected by a crisis if the decline in its growth rate is greater than its average annual growth rate. 
Table 1. Classification of emerging countries

\begin{tabular}{|l|l|l|}
\hline $\begin{array}{l}\text { Countries heavily affected } \\
\text { by the 1997 crisis }\end{array}$ & $\begin{array}{l}\text { Countries heavily affected } \\
\text { by the 2008 crisis }\end{array}$ & $\begin{array}{l}\text { Countries not strongly } \\
\text { affected by the two crises }\end{array}$ \\
\hline $\begin{array}{l}\text { Indonesia, Malaysia, } \\
\text { Thailand }\end{array}$ & $\begin{array}{l}\text { South Africa, Saudi Arabia, } \\
\text { Brazil, India, Iran Russia, } \\
\text { Turkey }\end{array}$ & China \\
\hline
\end{tabular}

Source: author according to WDI.

We note that the impact of the two crises differs from one country to another within the emerging countries.

According to Naoui et al. (2010), commercial links are presumed to have been the most important channel for transmitting the subprime crisis to emerging countries. Outside the direct trade channels, the crisis also led to an indirect decline in intra-regional trade in parts and components. Most of the industrial production of emerging countries (i.e. cars and parts, computers and electronic and electrical parts and appliances) is carried out through international production networks (IPNs), in which production is divided into stages and distributed in several companies in different countries, according to their respective comparative advantages. Declining demand for finished products in the G3 countries (United States, European Union and Japan) led to a decline in exports of parts and components from emerging countries.

China is the only country that has been able to cope with both crises. Unlike other countries affected by the Asian crisis, China benefited from a current account balance and substantial foreign exchange reserves and adopted well-structured banking and financial reforms (Fernald and Babson, 1999). In addition, it was able to cope with the 2008 crisis thanks to a very large recovery plan. It even experienced the backlash of this crisis, became the first supplier of Europe (Artus, Mistral, Plagnol, 2011). Indeed, Chinese companies have been able to take advantage of the financial deficit of Western companies, by lending them funds in exchange for an equity stake or control. This has allowed China to access new markets, to sell its goods. However, we note that from 2012, China experienced a slowdown in its growth (7.7\% in 2012 against $9.5 \%$ in 2011) ${ }^{11}$. According to Artus (2015), the first structural cause of this slowdown is the very rapid rise in its production costs. This is the result of a rather voluntarist policy of the Chinese government that raises wages by raising the minimum wage to support consumption.

After the subprime crisis, economic activity is quickly spread in emerging countries. However, in 2013, there was a rapid decline in growth rates in some emerging countries, including BRCS, Thailand and Turkey (see Figure 4).

\footnotetext{
${ }^{11}$ Author's calculations based on WDI data.
} 


\section{Macrothink}

Business and Economic Research

ISSN 2162-4860

2019, Vol. 9, No. 1

\subsection{Specialization Structure and Degree of Specialization of Emerging Countries}

\subsubsection{Specialization Structure of Emerging Countries}

In the present paper, we use the technological level and the level of natural resources (see section 1) to study the specialization of emerging countries in risk sectors.

\subsubsection{Technological Level of the Specialization of Emerging Countries and Crises}

To determine the technological level of the specialization of emerging countries, we used the index of specialization in high-tech manufactured articles.

We also use innovation proxies (Research and Development $(\mathrm{R} \& \mathrm{D})$ funding and the number of patent applications filed) to know the country's policy direction in the field of technology.

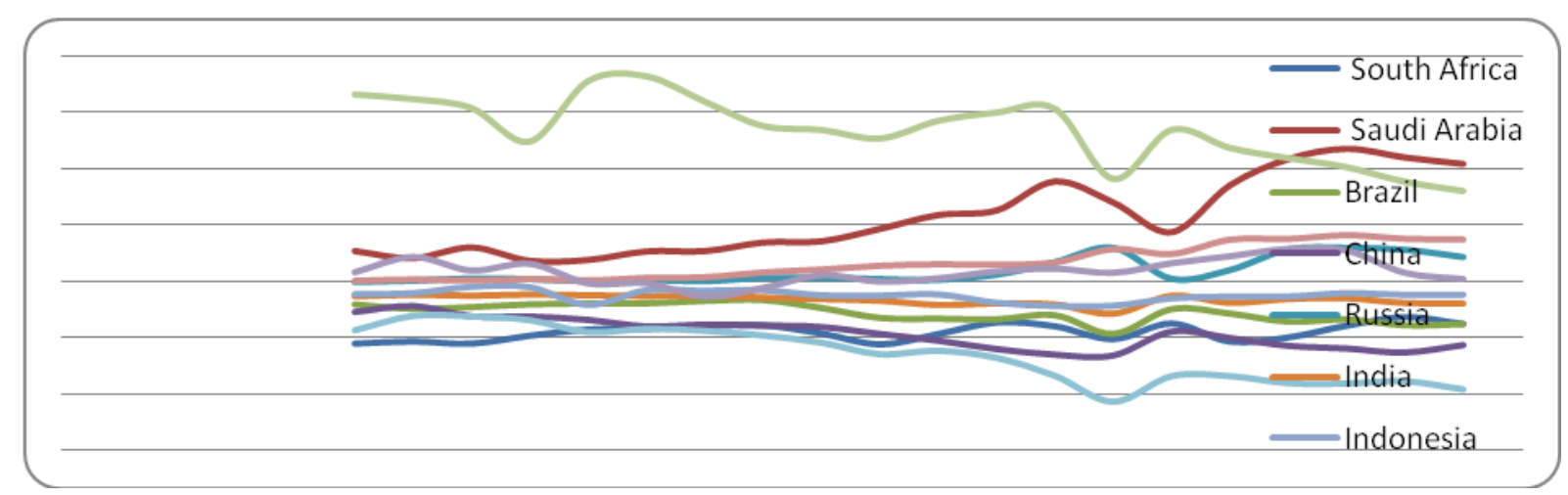

Figure 5. Specialization of emerging countries in high technology, 1995-2014

Source: Author's calculations based on WDI and Comtrade.

We note that less than half of the emerging countries (45\%) have specialized in high-tech manufactured goods. Saudi Arabia, Iran, Malaysia, Russia and Thailand are the countries that have registered a comparative advantage in high technology. This registered specialization may be due in part to assembly activities. According to CEPII (2002) and Feenstra and Wei (2010), the technology embodied in the exports of several emerging countries comes mainly from components produced in industrialized countries and does not reflect the technological innovation capacity of their manufacturing industry. 


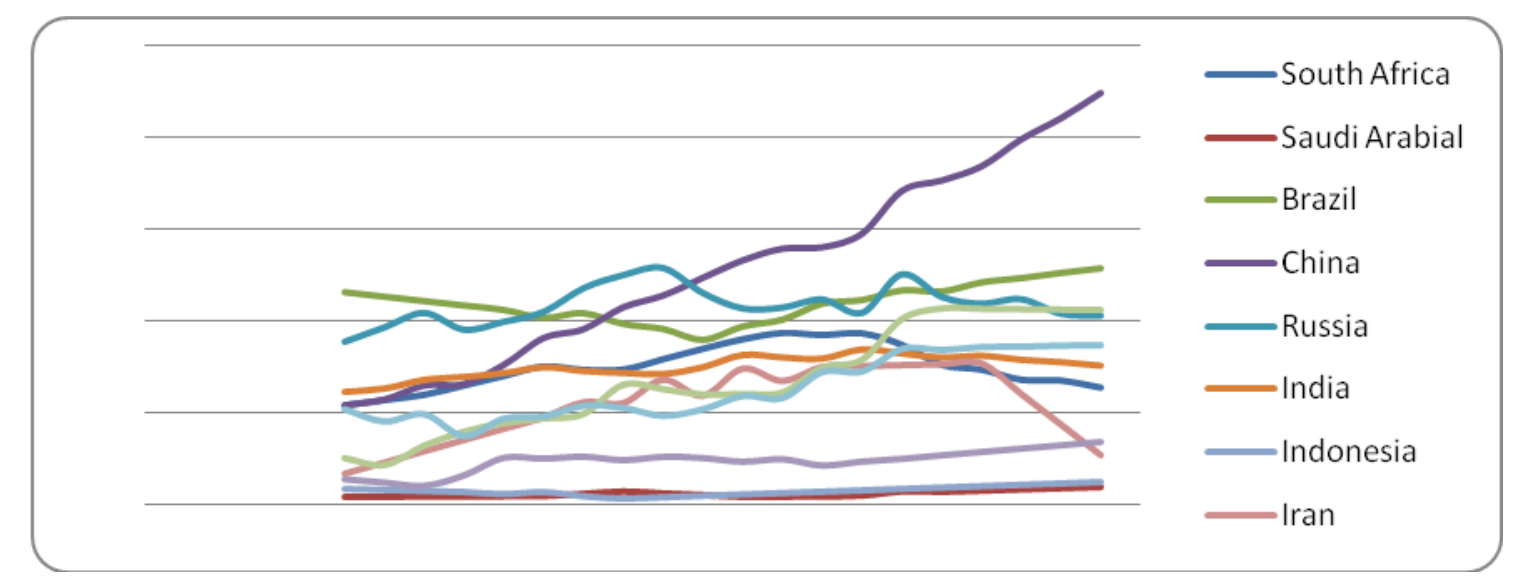

Figure 6. R \& D expenditure of emerging countries, 1995-2014, percentage of GDP Source: author's calculations based on WDI.

We find that China, Brazil, Malaysia and Russia are the emerging countries that spend the most on R \& D.

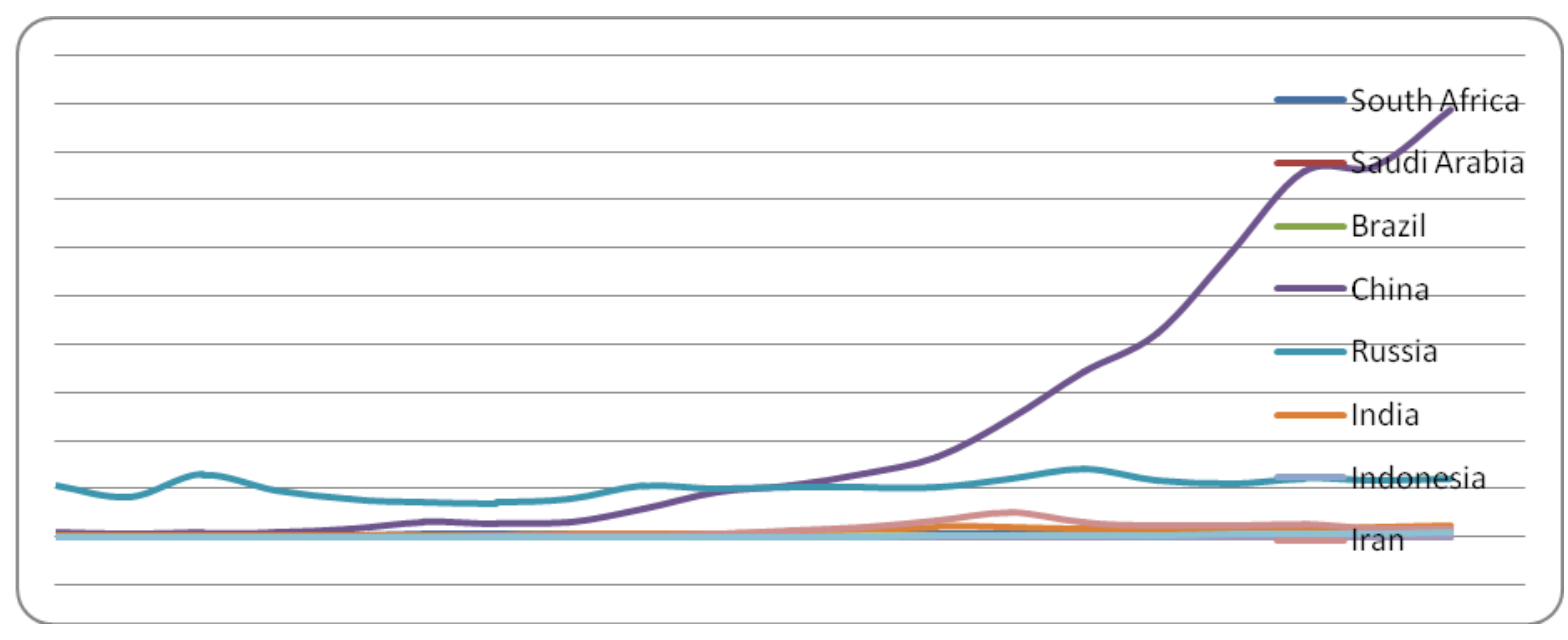

Figure 7. Number of Patent Applications, 1995-2014

Source: author according to WDI.

China and Russia are the two countries with the highest number of patent applications.

Based on the two proxies of innovation ( $\mathrm{R} \& \mathrm{D}$ funding and the number of patent applications), it appears that China, Brazil, Malaysia and Russia are the emerging countries that have invested the most in innovation and following the conclusions of the study by Kraay and Ventura (2006), these countries should be less exposed to crises.

\subsubsection{Specialization in Natural Resources and Crises}

To determine the level of specialization of emerging countries in natural resources, we first use the index of specialization in manufactured and labor-intensive manufactured goods and 
secondly the specialization in commodities ${ }^{12}$, precious stones and gold for non-monetary purposes $^{13}$.

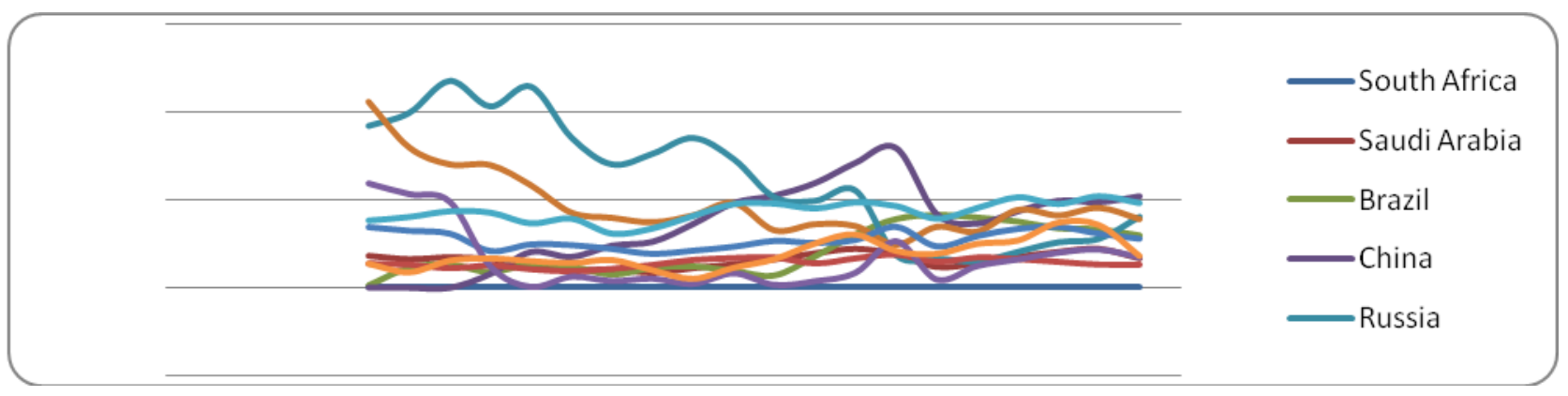

Figure 8. Specialization of Emerging Countries in Man-Made and Resource-Based Manufactured Articles in Emerging Countries, 1995-2014

Source: Author's calculations based on WDI and Comtrade.

We find that all emerging countries have specialized in labor-intensive and resource-based manufactured articles and that the level of specialization between 1995 and 2014 has not changed much except in China, Malaysia and China. In Russia, there is a sharp decrease. Brazil is the country with the highest growth in this sector.

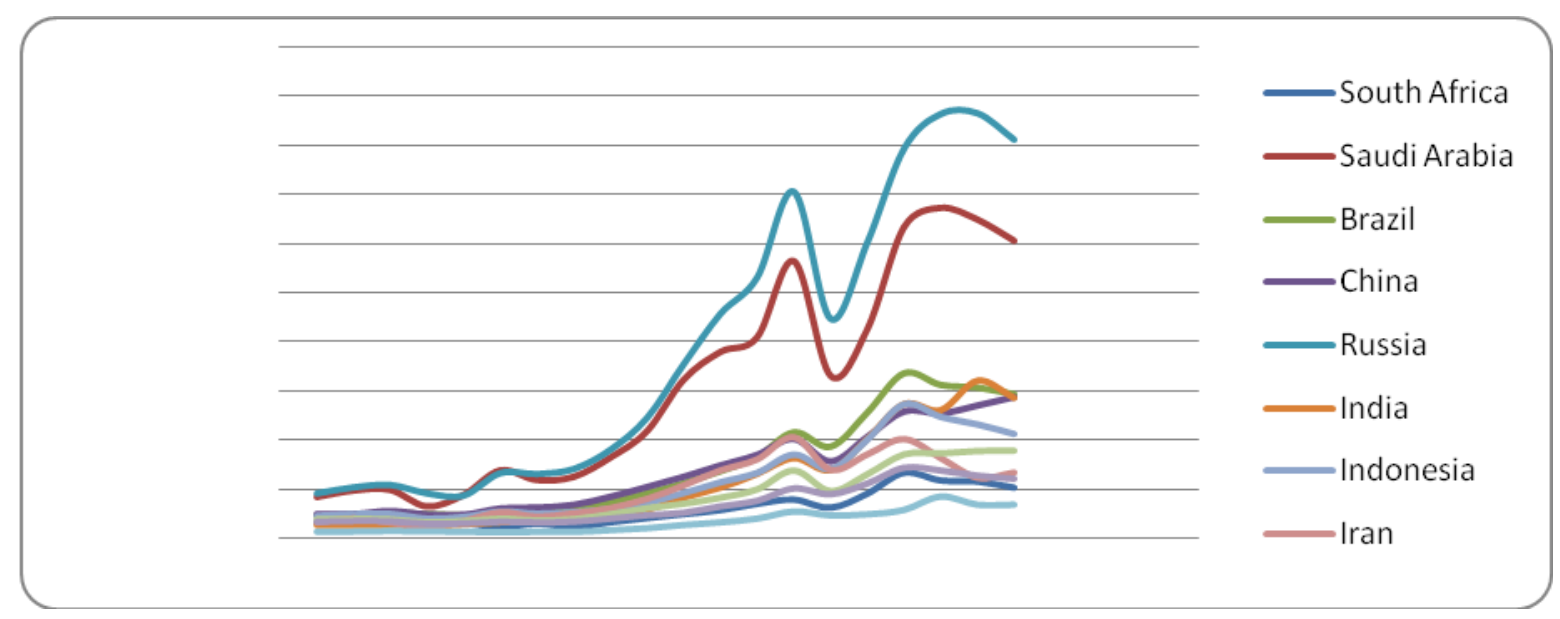

Figure 9. Specialization of Emerging Countries in Commodities, Gems and Gold for Non-monetary Purposes, 1995-2014

Source: Author's calculations based on WDI and Comtrade.

Saudi Arabia, Russia and Iran are the three countries that had a strong commodities specialization, while China, India and Turkey are the three countries with the lowest specialization in these products. According to Hausmann et al., (2004), Sachs and Warner (1997, 2001), the emerging countries and mainly Saudi Arabia, Russia and Iran should be the most vulnerable to crises because of their strong specialization in natural resources.

\footnotetext{
${ }^{12}$ Commodities refer to agricultural products and a number of other products that are classified as natural resources, such as fuels, forest products, ores and metals (UNCTAD, 2006).

${ }^{13}$ Classification used by UNCTAD (SITC, 0, 1, 2, 3, 4, 68, 667, 971).
} 
3.2.1.3 Degree of specialization of emerging countries and crises

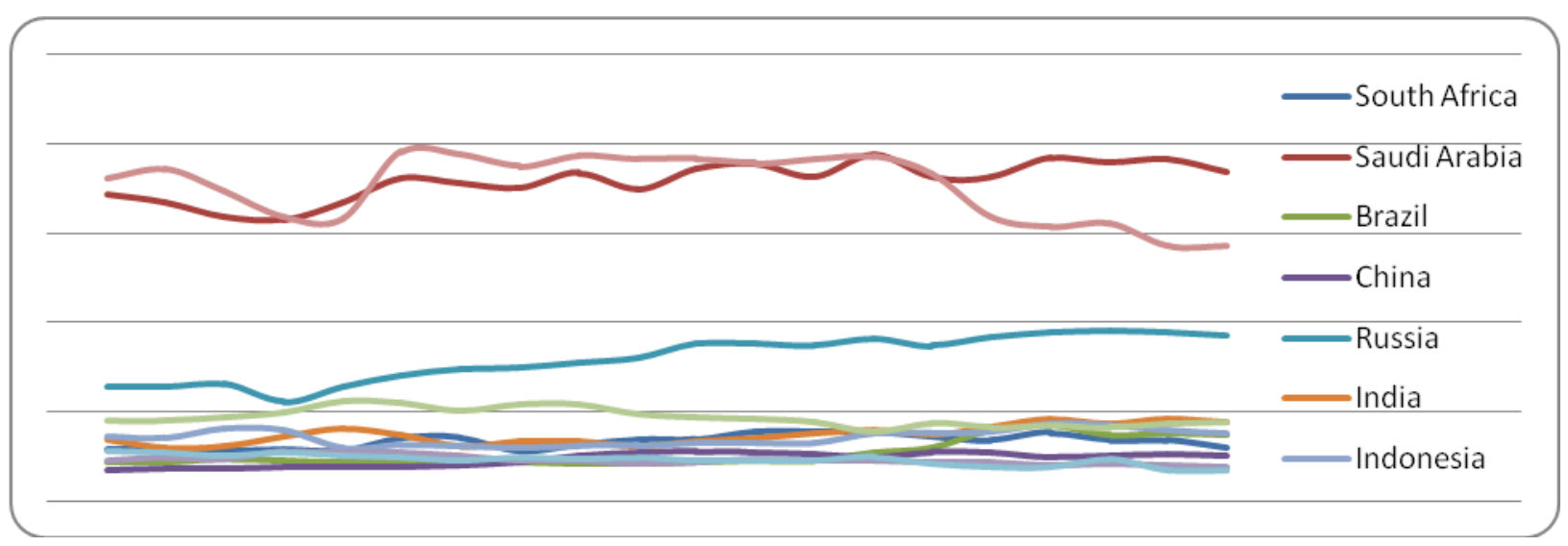

Figure 10. Concentration of exports from emerging countries, 1995-2014

Source: Comtrade.

In Figure 10, we note that the three emerging countries that have a high concentration of exports are the rentier countries, namely Saudi Arabia, Iran, and Russia. The other countries have an average concentration. Based on the literature (including Massell, 1964, Neto and Romeu, 2011 and Rose and Spiegel, 2011), rentier countries should be the most exposed to crises.

\section{Econometric Methodology}

In this section, we empirically study the impact of the specialization of emerging countries on economic instability and compare this impact with that of developed countries. To study this impact, we perform several tests that integrate different indicators of specialization.

\subsection{Model Specification and Measurement of Variables}

Our model is as follows:

$$
\Delta \mathrm{Y}_{\mathrm{it}}=\mathrm{u}_{\mathrm{i}}+\rho \operatorname{Spec}_{\mathrm{it}}+\Theta C \mathrm{~V}_{\mathrm{it}}+\varepsilon_{\mathrm{it}}
$$

\section{$>\quad$ Variable explained: economic instability}

According to the literature, there are three measures of economic instability. The first measure uses the standard deviation of the growth rate of one variable, the second uses the standard deviation of the residual of an econometric regression, and the third uses the standard deviation of the isolated cycle by a statistical filter. These three measures use the variance to calculate the differences. In our study, we use the first method (standard deviation of the GDP growth rate). This method is adopted mainly when the number of observations is not very important (Di Giovanni and Levchenko, 2010, and Van der Ploeg and Poelhekke, 2009).

\section{Variable of interest: specialization}

Specialization is our variable of interest. It may be the result of political orientation and / or 
factor endowments (essentially, natural resource endowments).

In this section, we estimate the impact of the degree and structure of specialization (technological level and level of natural resources) on economic stability.

Indicators that measure the level of innovation in specialization (see section 1.2.2) are:

- Specialization in high technology (ACR HT);

- Research and development expenditure as a percentage of GDP (DEP RD);

- The number of patent applications filed with patent offices (BREV).

Indicators that measure specialization in natural resources (see section 2.1.2) are:

- Specialization in labor-intensive and natural resource-based manufactured articles (ACR FORT);

- Specialization in commodities, precious stones and gold for non-monetary purposes (SPEC PDT BASE).

The indicator that measures the degree of specialization is the Export Concentration Index (CONC).

\section{$>$ Control variables}

- The initial wealth (Yi (t-1)) is measured by the logarithm of GDP per capita in Purchasing Power Parity for the year 1995. A negative sign is expected. Indeed, according to the literature (including Azeinman and Pinto 2005, Hnatkovska and Loayza 2004, Koren and Tenreyro 2007, Krishna and Levchenko 2009, Loayza et al., 2007, Lucas 1988 and Tapia 2012), there is a negative relationship between the standard deviation of annual per capita growth rates and the level of real GDP per capita.

- Investment (INVit) is measured by gross fixed capital formation. A negative sign is expected. This negative impact has been highlighted in many studies (including Price 1996, Driver Yip and Dakhil 1996).

- The stock of human capital (HC) is often approximated by the secondary school enrollment rate. Due to the lack of this data for Brazil, we used life expectancy at birth as proxy for human capital as proposed by Sala-I-Martin (1997). A negative sign is expected. This negative relationship has been found in empirical studies by Checchi and García-Peñalosa (2004), Flug et al. (1998) and Heylen and Vandewege (2005).

- Population growth (POP) as measured by population growth rate. The sign is indeterminate; it depends on the structure of the population.

- Integration to the international economy (OUV) measured by the ratio to GDP of the sum of exports and imports. According to the literature (including Corden and Neary, 1982, Guillaumont, 1994), instability is all the more important as the economy is more open. To mitigate the risk of instability, countries can adopt appropriate openness policies that are 
conducive to business competitiveness. The sign is uncertain.

- The terms of trade (TETR) are measured by the ratio of export prices to import prices. This indicator makes it possible to evaluate the purchasing power of exports in imports. A negative sign is expected. This negative relationship has been highlighted in Andrews and Rees (2005) study.

- Political stability (STPO) is measured by the index of political stability and the absence of violence (World Bank). A negative sign is expected. This negative impact was found in the studies of Giavazzi and Tabellini (2005) and Yang (2011).

\subsection{Econometric Method and Results}

Our sample includes 11 emerging countries and 36 developed countries ${ }^{14}$ over the period between 1995 and 2014. To study the impact of specialization on economic stability, we used the dynamic panel GMM method proposed by Arellano and Bover (1995) and Blundell and Bond (1998). This method is particularly suited to dynamic panels because it allows for any potential correlation between explanatory variables and country-specific factors. It does not require external instruments and uses delayed variables to correct the endogeneity bias (Holtz-Eakin et al., 1988, Arrelando and Bond 1991, Arrelando and Bover 1995).

\section{Results of estimates}

The results of the estimates are collated in Tables 2 and 3.

Table 2. Impact of Emerging Countries Specialization Structure on Economic Volatility in Emerging Countries ${ }^{15}$

\begin{tabular}{|l|l|l|l|}
\hline Variables of interest & Coefficients & T Std & P-value \\
\hline Specialization in high technology & $0.8762079 * * *$ & 2.89 & 0.004 \\
\hline Expenditures on research and development & $-0.3701642^{* * *}$ & -6.47 & 0.000 \\
\hline Patent applications & $-0.0331993^{*}$ & -1.73 & 0.085 \\
\hline $\begin{array}{l}\text { Specialization in labor-intensive manufactured } \\
\text { articles from natural resources }^{16}\end{array}$ & $4.945083^{*}$ & 1.49 & 0.138 \\
\hline Specialization in commodities & $0.0488497^{* *}$ & 2.20 & 0.029 \\
\hline Concentration index & -0.0734752 & -0.31 & 0.756 \\
\hline
\end{tabular}

The significant variables are $* * * 1 \%, * *$ à $5 \%$ ou $* 10 \%$

Table 3. Impact of developed countries' specialization structure on economic volatility in developed countries

\begin{tabular}{|l|l|l|l|}
\hline Variables of interest & Coefficients & T Std & P-value \\
\hline Specialization in high technology & $-0.0326638^{*}$ & -1.65 & 0.099 \\
\hline Expenditures on research and development & $-0.0113664 * * *$ & -7.38 & 0.000 \\
\hline
\end{tabular}

\footnotetext{
${ }^{14}$ According to the United Nations classification (see annex 4).

${ }^{15}$ See Appendix 5 for the results of all variables in the estimate.

${ }^{16}$ Can be considered weakly significant (probability $\approx 0.1$ ).
} 


\begin{tabular}{|l|l|l|l|}
\hline Patent applications & $-0.010851^{* * *}$ & -7.40 & 0.000 \\
\hline $\begin{array}{l}\text { Specialization in labor-intensive } \\
\text { manufactured articles from natural resources }\end{array}$ & $0.1503852^{* * *}$ & 5.40 & 0.000 \\
\hline Specialization in commodities & 0.0011723 & 0.35 & 0.729 \\
\hline Concentration index & 0.0009259 & 0.11 & 0.911 \\
\hline
\end{tabular}

The significant variables are $* * * 1 \%, * *$ à $5 \%$ ou $* 10 \%$

The coefficient of specialization in high technology manufactured goods is positive in emerging countries and negative in developed countries. This difference in the sign of the impact can be explained by a difference in the origin of the technology incorporated into the exports in these two categories of countries. According to CEPII (2003) and Feenstra and Wei (2010), the exports of emerging countries in high technology are not mainly based on innovation, but on assembly activities while the technology incorporated into exports developed countries is based primarily on innovation.

Research and development spending and the number of patent applications that reflect the country's political orientation in the field of technology both have a negative impact on the instability of emerging countries. For developed countries, this is the case for the first, but the impact of the number of patent applications is not significant. Thus, countries that are more innovative are likely to be less volatile. This negative relationship with instability confirms that found by Koren and Tenreyro (2007), Kraay and Ventura (2006) and Tapia (2012).

Specialization in labor-intensive manufactures and specialization in commodities has a positive impact on instability in both (emerging and developed) countries. The latter is mainly due to the volatility of world commodity prices. This result confirms that found by Blattman et al., (2007), Hausmann et al., (2004), Ploeg and Poelhekke (2009) and Sachs and Warner $(1997,2001)$ who find that countries that specialize in products at unstable prices (essentially, countries with endowments of natural resources) are more volatile.

The degree of concentration of emerging countries as well as that of developed countries is insignificant. This non-significance can be explained by a difference in the concentration sectors of exports (essentially a difference on the technological level) within these two categories of countries.

These results suggest that an increase in the use of new technologies in production and a decrease in the dependency of natural resources could be able to reduce the instability of emerging countries.

\section{Conclusion}

As emerging countries are characterized by high vulnerability, their development process is likely to be severely hampered by shocks; which contributes to a strong instability of their economic growth. To understand this high vulnerability of emerging countries, we explored the impact of structure and degree of specialization on economic instability.

Using the dynamic GMM model on a panel of 11 emerging countries and 36 developed countries between 1995 and 2014, we found that the unstable nature of emerging countries 
can be explained firstly by their specialization in high-intensity manufactured goodsand secondly, by their specialization in high-tech manufactured goods coming mainly from assembly activities and not from innovation. This instability can be reduced in countries that encourage innovation. The latter was measured by the proxies that are the funding in $R \& D$ and the number of patents filed.

We suggest then that a decrease in the specialization of these countries in risky sectors, especially those based on natural resources, as well as an increase in the use of high technology in their production may reduce instability emerging economies.

\section{References}

Andrews, D.,\& Rees, D. (2005).Macroeconomic Volatility and Terms of Trade Shocks Economic.Analysis Department Reserve Bank of Australia.

Arellano, M., \& Bond, S. (1991).Some Tests of Specification for Panel Data: Monte Carlo Evidence and an Application to Employment Equations. Review of Economic Studies, 58(2),277-297.

Arellano, M., \&Bover, O. (1995).Another Look at the Instrumental Variable Estimation of Error-Components Models.Journal of Econometrics, 68(1), 29-51.

Artus, P., Mistral, J., \& Plagnol, V. (2011). L'émergence de la Chine : impact économique et implications de politique économique. Economic Analysis Council.

Azeinman, J., \& Pinto, B. (2005).Managing Volatility and Crises: A Practitioner's Guide Overview, Cambridge: Cambridge University Press.

Balassa, B. (1965). Trade Liberalization and Revealed Comparative Advantage. Manchester School of Economics and Social Studies, 2,99-123.

Becker, G.S., \& Murphy, K.M. (1992).The Division of Labor, Coordination Costs and Knowledge.the Quarterly Journal of Economic, 107(4), 1137-1160.

Blanchard, O.J., \& Kremer, M.(1997).Disorganization.Quarterly Journal of Economics, 112(4), 1091-1126. https://doi.org/10.1162/003355300555439

Blattman, C., Hwang, J., \& Williamson, J. (2004).Winners and Losers in the Commodity Lottery: The Impact of Terms of Trade Growth and Volatility. Working Paper in the Periphery, 1870-1939. https://doi.org/10.1016/j.jdeveco.2005.09.003

Bleaney, M., \&Halland, H. (2014).Natural Resource Exports, Fiscal Policy Volatility and Growth.Scottish Journal of Political Economy, 61(5), 502-522.

https://doi.org/10.1111/sjpe.12055

Blundel, R., \& Bond, S. (1998). Initial Conditions and Moment Restrictions in Dynamic Panel Data Models.Journal of Econometrics, 87, 115-143.

https://doi.org/10.1016/S0304-4076(98)00009-8

Brunnschweiler, C.N., \&Bulte, E.H. (2008).Natural Resources and Violent Conflict: 
Resource Abundance, Dependence and the Onset of Civil Wars. Oxford Economic Papers, 61(4), 651-674. https://doi.org/10.1093/oep/gpp024

Cariolle, J. (2011). L'indice de vulnérabilitééconomiquerétrospectif.Working Paper, Foundation for Studies and Research on International Development.

CEPII (Center for Prospective Studies and International Information) (2002). Chine: spécialisation internationale, \& rattrapage technologique. the French Documentation.International Economics, 4(92), 11-40.

Cheewatrakoolpong, K., \&Manprasert, S. (2015). Trade Diversification and Crisis Transmission: A Case Study of Thailand. Asian Economic Journal, 4(29), 385-408. https://doi.org/10.1111/asej.12080

Combes, J.L., \&Guillaumont, P. (2002).Commodity Price Volatility, Vulnerability and Development.Development Policy Review, 20(1), 25-39.

https://doi.org/10.1111/1467-7679.00155

Corden, W.M. (1982). Exchange Rate Policy and the Resources Boom.Economic Record, 58(1),18-31.

Costinot, A. (2009). An Elementary Theory of Comparative Advantage.Econometrica, 77(4), 1165-1192. https://doi.org/10.3982/ECTA7636

Da Costa, N. N.C., \&Romeu, R. (2011).Did Export Diversification Soften the Impact of the Global Financial Crisis?.International Monetary Fund working papers.

Dawe, D. (1996). A New Look at the Effects of Export Instability on Investment and Growth. World Development, 24(12), 1905-1914. https://doi.org/10.1016/S0305-750X(96)00080-0

Dehn, J. (2000). Commodity Price Uncertainty in Developing Countries.Policy Research Working Paper, 2426.https://doi.org/10.1596/1813-9450-2426

Di Giovanni, J., \& Levchenko, A.A.(2009). Trade Openness and Volatility.Review of Economics and Statistics, 91(3), 558-585. https://doi.org/10.1162/rest.91.3.558

Di Giovanni, J., \&Levchenko, A.A. (2010).The Risk Content of Exports: A Portfolio View of International Trade. NBER Working Papers, National Bureau of Economic Research, (16005).

Di Giovanni, J., Levchenko, A.A., \&Méjean, L. (2012).Firms, Destinations, and Aggregate Fluctuations.Working Papers, Research Seminar in International Economics, University of Michigan, (630). https://doi.org/10.3982/ECTA11041

Ding, N., \& Field, B.C. (2005). Natural Resource Abundance and Economic Growths.Land Economics, 81(4), 496-502. https://doi.org/10.3368/le.81.4.496

Fatás, A., \&Mihov, I. (2005).Policy Volatility, Institutions and Economic Growth.Working Paper, Centre for Economic Policy Research, 5388. https://doi.org/10.1162/REST_a_00265

Feenstra, R.C., \& Wei, S.J. (2010).Introduction to China's Growing Role in World Trade, Chicago: University of Chicago Press. 


\section{Ml Macrothink}

Business and Economic Research ISSN 2162-4860 2019, Vol. 9, No. 1

Fernald, J.G., \& Babson, O. (1999).Why has China Survived the Asian Crisis so Well? What Risks remain?.International Finance DiscussionPapers, 633, Board of Governors of the Federal Reserve System (U.S). http://dx.doi.org/10.2139/ssrn.154629

Fernandez, E., \& Steel, M. (2001).Model Uncertainty in Cross-Country Growth Regressions.Journal of Applied Econometrics, 16(5), 563-576. https://doi.org/10.1002/jae.623

Guillaumont, P., Guillaumont-Jeanneney, S., \&Brun, J.F. (1999).How Instability Lowers African Growth. Journal of African Economies, 8(1), 87-107. https://doi.org/10.1093/jae/8.1.87

Guillaumont, P. (2007). Economic Vulnerability, Persistent Challenge to African Development. Revue Africaine du Développement, 19(1), 123-162.

Guillaumont, P. (2009). An Economic Vulnerability Index: Its Design and Use for International Development Policy. Oxford Development Studies, 37(3), 193-228. https://doi.org/10.1080/13600810903089901

Guillaumont, P. (2010). Assessing the Economic Vulnerability of Small Island Developing States and the Least Developed Countries.Journal of Development Studies, 46(5), 828-854. https://doi.org/10.1080/00220381003623814

Guttmann, S., \& Richards, A. (2006).Trade Openness: an Australian Perspective. Australian Economic Papers, 45(3), 188-203. https://doi.org/10.1111/j.1467-8454.2006.00287.x

Helpman, E., \&Razin, A. (1978). Uncertainly and International Trade in The Presence of Stock Markets.Working Paper, TheFoerder Institute for Economic Research, 96.

Hausmann, R., Panizza, U., \&Rigobon, R. (2004).The Long-Run Volatility Puzzle of the Real Exchange Rate.NBER Working Papers, National Bureau of Economic Research, 10751. https://doi.org/10.1016/j.jimonfin.2005.10.006

Hidalgo, C., \&Hausmann, R. (2009).The Building Blocks of Economic Complexity.Proceedings of the National Academy of Sciences, 106, 10570-10575. https://doi.org/10.1073/pnas.0900943106

Hnatkovska, V., \&Loayza, N. (2005).Volatility and Growth.in J. Azeinman et B. Pinto (eds.) Managing Economic volatility and Crises,Cambridge, Mass: Cambridge University Press.

Holtz-Eakin, D., Newey, W., \& Rosen, H.S. (1988).Estimating Vector Autoregression with Panel Data.Econometrica, 56(6), 1371-1395.

Imbs, J. (2007). Growth and Volatility.Journal of Monetary Economics, 54(7), 1848-1862. https://doi.org/10.1016/j.jmoneco.2006.08.001

Koren, M., \&Tenreyro, S. (2007).Volatility and Development.Quarterly Journal of Economics, 122(1), 243-287. https://doi.org/10.1162/qjec.122.1.243

Krishna, P., \&Levchenko, A. (2013).Comparative Advantage, Complexity, And Volatility. 
Journal of Economic Behavior and Organization, 94, 314-329.

https://doi.org/10.1016/j.jebo.2012.11.004

Levchenko, A.A. (2007). Institutional Quality and International Trade.Review of Economic Studies, 74(3), 791-819. https://doi.org/10.1111/j.1467-937X.2007.00435.x

Loayza, N.V., \&Raddatz, C. (2007).The Structural Determinants of External Vulnerability.World Bank Economic Review, 21(3), 359-387. https://doi.org/10.1093/wber/lhm018

Loayza, N.V., Rancière, R., Servén, L., \& Ventura, J. (2007).Macroeconomic Volatility and Welfare in Developing Countries: An Introduction. World Bank Economic Review, 21(3), 343-357. https://doi.org/10.1093/wber/lhm017

Lucas, R. (1988). On the Mechanics of Economic Development.Journal of Monetary Economics, 22(1), 3-22. https://doi.org/10.1016/0304-3932(88)90168-7

Massell, B.F. (1964). Export Concentration and Fluctuations in Export Earnings: A Cross Section Analysis. The American Economic Review, 34(2), 47-63.

Mauro, P., \& Becker, T. (2006).Output Drops and the Shocks that Matter. IMF Working Papers, International Monetary Fund, 06-172.

Meilak, C. (2008). Measuring Export Concentration: the Implications for Small States.Bank of Valletta Review, 37, 35-48.

Nunn, N. (2007). Relationship-Specificity, Incomplete Contract, and the Pattern of Trade.Quarterly Journal of Economics, 122(2), 569-600. https://doi.org/10.1162/qjec.122.2.569

Plihon, D. (2008). Lutter contre l'instabilité financière : pour un aggiornamento de la théorie et de la régulation financières. Financial Economics Review, 7(1), 433-437.

Raddatz C. (2007). Are External Shocks Responsible for the Instability of Output in Low-Income Countries?.Journal of Development Economics, 84(1), 155-187.

https://doi.org/10.1596/1813-9450-3680

Rancière, R., Tornell, A., \&Westermann, F. (2008).Systemic Crises and Growth.Quarterly Journal of Economics, 123(1), 359-406. https://doi.org/10.1162/qjec.2008.123.1.359

Rodrik, D. (1998). Why Do Open Economies Have Bigger Governments?.Journal of Political Economy, 106(5), 997-1032. https://doi.org/10.1086/250038

Sachs, J., \& Warner, A. (1995).Natural Resource Abundance and Economic Growth.NBER Working Paper, 5398, National Bureau of Economic Research.

Sachs, J.D., \& Warner, A.M. (1997).Natural Resources and Economic Growth.National Bureau of Economic Research Working paper, Cambridge, MA, (5398).

Sachs, J.D., \& Warner, A.M. (2001).Natural Resources and Economic Development. The Curse of Natural Resources.European Economic Review,45, 827-838. 
https://doi.org/10.1016/S0014-2921(01)00125-8

Sala-i-Martin, X. (1997).I Just Ran Two Million Regressions. American Economic Review, 87(2), 178-183. https://doi.org/10.3386/w6252

Tapia, H. (2012). Economic Policies, Volatility and Development.Thèse, Columbia: Columbia University.

Turnovsky, S. J. (1974). Technological and Price Uncertainly in a Ricardian Model of International Trade.Review of Economic Studies, 41(2), 201-217.

Van der Ploeg, F. (2008).Challenges and Opportunities for Resource Rich Economies.OxCarre Working Paper, 005.

Yang, B. (2011).Political Democratization, Economic Liberalization, and Growth Volatility.Journal of Comparative Economics, 39(2), 245-259.

https://doi.org/10.1016/j.jce.2010.08.001

\section{Appendix}

Appendix 1.The measure of specialization

The balance contribution indicator is defined as follows:

$\operatorname{CTB}_{i k}=\frac{1000}{Y P P A_{i}}\left[\left(X_{i k}^{v}-M_{i k}^{v}\right)-\frac{W_{k}}{W}\left(X_{i,}^{v}-M_{i=}^{v}\right)\right]$

with, $i$ the country, $k$ the product, YPPAle PIB expressed in purchasing power parity

$$
X_{i k}^{\prime}=X_{i k} * \frac{W_{K}^{r}}{W^{r}} / \frac{W_{k}^{t}}{W^{t}} M_{i k}^{\prime}=M_{i k} * \frac{W_{k}^{r}}{W^{r}} / \frac{W_{k}^{t}}{W^{t}}
$$

$X$ the exports, $M$ the imports by value

The world trade in the product $\mathrm{k}$ the reference year $\mathrm{r}$ (2005 for us)

$W_{k}^{r}$ : The world trade in the product $\mathrm{k}$ the reference year $\mathrm{r}$ (2005 for us)

$w_{k}^{t}$ : The world trade in the product $\mathrm{k}$ year $\mathrm{t}$,

$w^{r}=\sum_{k} w_{k}^{r}$ et $w^{t}=\sum_{k} w_{k}^{t}$ le commerce mondial des années $r$ et $t$.

$X_{i}^{\prime}=\sum_{k} X_{i k}^{\prime} M_{i}^{\prime}=\sum_{k} M_{i k}^{\prime}$ 
Appendix 2.Groupings of manufactured articles by level of manufacture according to SITC rev. 3

\begin{tabular}{|l|l|}
\hline Code & Wording \\
\hline Manufactured articles with a high labor intensity and from natural resources \\
\hline 61 & Hides and skins, prepared and dressed \\
\hline 63 & Cork and wood work (except furniture) \\
\hline 64 & Papiers et préparations de papier \\
\hline 65 & Yarns, fabrics and shaped articles \\
\hline 66 sauf 667 & Manufactured non-metallic mineral articles, nes \\
\hline 821 & Furniture and parts; similar bedding items \\
\hline 831 & Travel goods, handbags and the like \\
\hline 84 & Apparel and clothing accessories \\
\hline 851 & Shoes \\
\hline High technology and high skill manufactures \\
\hline $751,752,761,762,763$ & Electronic products except parts and components \\
\hline $759,764,776$ & Parts and components of electrical and electronic products \\
\hline $\begin{array}{l}511--516,52-, 525,531-533,541,542, \\
551,553,554,562,571-575,579,\end{array}$ & Other, except electronic \\
$581-583,591-593,597,598$, & \\
$792,871-874,881-885,891,892,896-898$ & \\
\hline
\end{tabular}

Appendix 3.Choice of the sample

In the literature, there is no consensus on the definition of the emergence and the concept appears complex and composite. It varies by author and organization as well as over time.

In order to determine the list of emerging countries, we started from the criteria most used by different authors and organizations, namely economic growth, standard of living, commercial and financial integration, degree of reform and economic weight. However, if not sometimes China, no country meets these five criteria. Given these difficulties, we chose to cross a criterion of economic growth and a criterion of commercial integration, namely:

- PPP GDP growth above the world average and

- The average exports of goods and services relative to global exports above the world average.

The choice of the criterion of economic growth is justified by the fact that an emerging country is essentially characterized by a strong economic growth. Nevertheless, the latter is not always higher in emerging countries than in other groups of countries. To correct these distortions, we added the criterion of commercial integration, which seems to us essential knowing that our question is about international specialization.

The resulting list contains 10 countries: Brazil, China, Russia, India, Indonesia, Iran, Malaysia, Thailand, Turkey and Thailand, to which we added South Africa. Indeed, this country meets the criterion of economic growth but presents the smallest difference $(0.0002)$ 
for the criterion of commercial integration. Given this small difference and the fact that South Africa is considered an emerging country by international organizations, we have introduced it into our country list.

Appendix 4. List of developed countries

Australia, Austria, Belgium, Bulgaria, Canada, Cyprus, Croatia, Czech Republic, Denmark, Estonia, Finland, France, Germany, Greece, Hungary, Iceland, Ireland, Israel, Italy, Japan, Latvia, Luxembourg, Malta, Spain, Monaco, Norway, New Zealand, Netherlands, Poland, Portugal, Slovak Republic, Czech Republic, Romania, United Kingdom, Slovenia, Sweden, Switzerland.

Appendix 5. Estimated results

Results of estimates of the relationship between specialization in high technology and economic stability in emerging and developed countries

\begin{tabular}{|c|c|c|}
\hline Variables / Countries & Emerging countries & Developed countries \\
\hline Inst(L1) & $\begin{array}{l}0.8695567 * * * \\
(32.55)\end{array}$ & $\begin{array}{l}0.7707613^{* * * *} \\
(34.19)\end{array}$ \\
\hline $\mathrm{Yi}(\mathrm{t}-1)$ & $\begin{array}{l}-0.1198191 * * \\
(-2.19)\end{array}$ & $\begin{array}{l}-0.0212442 * * * \\
(-7.43)\end{array}$ \\
\hline INVit & $\begin{array}{l}0.0558032 \\
(0.91)\end{array}$ & $\begin{array}{l}-0.0117517 * * * \\
(-7.49)\end{array}$ \\
\hline $\mathrm{HC}$ & $\begin{array}{l}-0.7482251 * * * \\
(-3.40)\end{array}$ & $\begin{array}{l}-0.0055073 \\
(-0.58) \\
\end{array}$ \\
\hline POP & $\begin{array}{l}-0.0063506 \\
(-0.28) \\
\end{array}$ & $\begin{array}{l}0.0006161 \\
(1.23)\end{array}$ \\
\hline OUV & $\begin{array}{l}0.0101821 \\
(0.21)\end{array}$ & $\begin{array}{l}0.0065384 * * * \\
(2.78)\end{array}$ \\
\hline TETR & $\begin{array}{l}-0.0008214 \\
(-0.42) \\
\end{array}$ & $\begin{array}{l}-0.0053528 \\
(-1.50) \\
\end{array}$ \\
\hline STPO & $\begin{array}{l}-0.3973985 * * * \\
(-2.71)\end{array}$ & $\begin{array}{l}-0.0040606 \\
(-1.40) \\
\end{array}$ \\
\hline ACR HT & $\begin{array}{l}0.8762079 * * * \\
(2.89)\end{array}$ & $\begin{array}{l}-0.0326638^{*} \\
(-1.65) \\
\end{array}$ \\
\hline & $\begin{array}{l}\text { Nombre des observations }=198 \\
F(9,189)=312.85 \\
\text { Prob }>F=0.000 \\
\text { Prob }>\text { chi } 2=0.000\end{array}$ & $\begin{array}{l}\text { Nombre des observations }=644 \\
F(9,635)=1765.32 \\
\text { Prob }>F=0.000 \\
\text { Prob }>\text { chi } 2=0.000\end{array}$ \\
\hline
\end{tabular}

Results of estimates of the relationship between research and development spending and economic stability in emerging and developed countries

\begin{tabular}{|l|l|l|}
\hline Variables / Countries & Emerging countries & Developed countries \\
\hline Inst $(\mathrm{L} 1)$ & $0.8449191 * * *$ & $0.7731232 * * *$ \\
\hline
\end{tabular}




\begin{tabular}{|l|l|l|}
\hline & $(29.98)$ & 35.03 \\
\hline Yi(t-1) & $-0.3718017 * * *$ & $-0.021034 * * *$ \\
& $(-5.11)$ & -7.37 \\
\hline INVit & -0.0628126 & 0.0006791 \\
& $(-0.92)$ & 0.75 \\
\hline HC & $-0.6831906 * * *$ & -0.0045981 \\
& $(-3.18)$ & -0.49 \\
\hline POP & 0.0008199 & -0.0045981 \\
& $(0.04)$ & 0.74 \\
\hline OUV & -0.0312651 & 0.0056794 \\
& $(-0.62)$ & 2.43 \\
\hline TETR & -0.0003561 & -0.0033477 \\
& $(-0.18)$ & -1.00 \\
\hline STPO & $-0.5021731 * * *$ & -0.0039524 \\
& $(-3.35)$ & -1.35 \\
\hline DEP RD & $-0.3701642 * * *$ & $-0.0113664 * * *$ \\
& $(-6.47)$ & -7.38 \\
\hline & Nombre des observations $=198$ & Nombre des observations $=644$ \\
& $\mathrm{~F}(9,189)=310.16$ & $\mathrm{~F}(9,635)=1762.60$ \\
& Prob> F $=0.000$ & Prob $>\mathrm{F}=0.000$ \\
& Prob> chi2 $=0.000$ & Prob> chi2 $=0.000$ \\
\hline & & \\
& & \\
& &
\end{tabular}

Results of estimates of the relationship between patent applications and economic stability in emerging and developed countries

\begin{tabular}{|l|l|l|}
\hline Variables / Countries & Emerging countries & Developed countries \\
\hline Inst(L1) & $0.8975019 * * *$ & $0.7763915^{* * *}$ \\
& $(32.72)$ & $(35.39)$ \\
\hline Yi(t-1) & $-0.1217507 *$ & $-0.0206112^{* * *}$ \\
& $(-1.70)$ & $(-7.17)$ \\
\hline INVit & 0.0348263 & 0.0003409 \\
& $(0.52)$ & $(0.45)$ \\
\hline HC & $-0.6308798^{* * *}$ & -0.0034859 \\
& $(-2.86)$ & $(-0.37)$ \\
\hline POP & -0.0190466 & 0.0002882 \\
& $(-0.82)$ & $(0.55)$ \\
\hline OUV & 0.0317302 & $0.0065746 * * *$ \\
& $(0.62)$ & $(2.83)$ \\
\hline TETR & 0.0005116 & -0.004962 \\
& $(0.25)$ & $(-1.46)$ \\
\hline STPO & $-0.5486532 * * *$ & -0.0042701 \\
& $(-3.39)$ & $(-1.47)$ \\
\hline BREV & $-0.0331993 *$ & $-0.010851 * * *$ \\
& $(-1.73)$ & $(-7.40)$ \\
\hline
\end{tabular}




\begin{tabular}{|l|l|l|}
\hline Nombre des observations $=191$ & Nombre des observations =644 \\
& $\mathrm{F}(9,182)=278.88$ & $\mathrm{~F}(9,635)=1773.46$ \\
Prob $>\mathrm{F}=0.000$ & $\begin{array}{l}\text { Prob }>\mathrm{F}=0.000 \\
\text { Prob }>\text { chi2 }=0.000\end{array}$ & Prob> chi2 $=0.000$ \\
\hline
\end{tabular}

Results of estimates of the relationship between specialization in labor-intensive and resource-based manufactured goods and economic stability in emerging and developed countries

\begin{tabular}{|c|c|c|}
\hline Variables / Countries & Emerging countries & Developed countries \\
\hline $\operatorname{Inst}(\mathrm{L} 1)$ & $\begin{array}{l}0.8649422 * * * \\
(31.79)\end{array}$ & $\begin{array}{l}0.8184832 * * * \\
(39.08)\end{array}$ \\
\hline $\mathrm{Yi}(\mathrm{t}-1)$ & $\begin{array}{l}-0.1224586^{* *} \\
(-2.12)\end{array}$ & $\begin{array}{l}-0.0133956 * * * \\
(-4.84)\end{array}$ \\
\hline INVit & $\begin{array}{l}-0.0109138 \\
(-0.12)\end{array}$ & $\begin{array}{l}0.0018742 * * * \\
(2.55)\end{array}$ \\
\hline $\mathrm{HC}$ & $\begin{array}{l}-0.9563799 * * * \\
(-4.33)\end{array}$ & $\begin{array}{l}-0.0073341 \\
(-0.76)\end{array}$ \\
\hline POP & $\begin{array}{l}-0.0107373 \\
(-0.47)\end{array}$ & $\begin{array}{l}0.0000117 \\
(0.02)\end{array}$ \\
\hline OUV & $\begin{array}{l}0.0222825 \\
(0.46)\end{array}$ & $\begin{array}{l}0.006415 * * * \\
(2.71)\end{array}$ \\
\hline TEtr & $\begin{array}{l}-0.0007147 \\
(-0.37)\end{array}$ & $\begin{array}{l}-0.000303 \\
(-0.08)\end{array}$ \\
\hline STPO & $\begin{array}{l}-0.3585523 * * \\
(-2.44)\end{array}$ & $\begin{array}{l}-0.0007479 \\
(-0.25)\end{array}$ \\
\hline ACR FORT & $\begin{array}{l}4.945083 \\
(1.49)\end{array}$ & $\begin{array}{l}0.1503852 * * * \\
(5.40)\end{array}$ \\
\hline & $\begin{array}{l}\text { Nombre des observations }=198 \\
F(9,189)=317.47 \\
\text { Prob }>F=0.000 \\
\text { Prob }>\text { chi } 2=0.000\end{array}$ & $\begin{array}{l}\text { Nombre des observations }=644 \\
F(9,635)=1663.34 \\
\text { Prob }>F=0.000 \\
\text { Prob }>\text { chi } 2=0.000\end{array}$ \\
\hline
\end{tabular}

Results of estimates of the relationship between specialization in commodities and economic stability in emerging and developed countries

\begin{tabular}{|l|l|l|}
\hline Variables / Countries & Emerging countries & Developed countries \\
\hline Inst(L1) & $0.8702653^{* * *}$ & $0.8509861^{* * *}$ \\
& $(32.46)$ & $(42.06)$ \\
\hline Yi(t-1) & -0.0012143 & $-0.0115455^{* * * *}$ \\
& $(-0.02)$ & $(-4.33)$ \\
\hline INVit & 0.0576434 & 0.0011236 \\
& $(0.92)$ & $(1.44)$ \\
\hline Hc & $-0.8695246^{* * *}$ & -0.0131052 \\
& $(-4.03)$ & $(-1.33)$ \\
\hline
\end{tabular}




\begin{tabular}{|l|l|l|}
\hline POP & -0.0030012 & -0.0000997 \\
& $(-0.13)$ & $(-0.19)$ \\
\hline OUV & -0.0129182 & $0.006598^{* * *}$ \\
& $(-0.26)$ & $(2.75)$ \\
\hline TETR & -0.0016507 & -0.0044317 \\
& $(-0.84)$ & $(-1.33)$ \\
\hline STPO & $-0.3067627^{* *}$ & -0.0030638 \\
& $(-1.98)$ & $(-1.00)$ \\
\hline SPEC PDT BASE & $0.0488497 * *$ & 0.0011723 \\
& 2.20 & 0.35 \\
\hline & Nombre des observations $=198$ & Nombre des observations $=644$ \\
& F $(9,189)=321.92$ & F $(9,635)=1633.00$ \\
& Prob> F $=0.000$ & Prob $>$ F $=0.000$ \\
& Prob $>$ chi2 $=0.000$ & Prob $>$ chi2 $=0.000$ \\
\hline
\end{tabular}

Results of estimates of the relationship between concentration index and economic stability in emerging and developed countries

\begin{tabular}{|l|l|l|}
\hline Variables / Countries & Emerging countries & Developed countries \\
\hline Inst(L1) & $0.8750232^{* * *}$ & $0.8518479^{* * *}$ \\
& $(32.81)$ & $(42.01)$ \\
\hline Yi(t-1) & -0.085807 & $-0.0121993 * * *$ \\
& $(-1.54)$ & $(-4.37)$ \\
\hline INVit & 0.0876131 & 0.0010223 \\
& $(1.43)$ & $(1.28)$ \\
\hline HC & $-0.7909217 * * *$ & -0.0134403 \\
& $(-3.48)$ & $(-1.37)$ \\
\hline POP & 0.0003454 & -0.0002211 \\
& $(0.01)$ & $(-0.41)$ \\
\hline OUV & 0.0399205 & $0.0058869 * *$ \\
& $(0.84)$ & $(2.41)$ \\
\hline TETR & 0.0001565 & -0.0052149 \\
& $(0.08)$ & $(-1.47)$ \\
\hline STPO & $-0.3967879 * * *$ & -0.0027181 \\
& $(-2.70)$ & $(-0.90)$ \\
\hline CONC & -0.0734752 & 0.0009259 \\
& $(-0.31)$ & $(0.11)$ \\
\hline & Nombre des observations $=198$ & Nombre des observations $=644$ \\
& F $(9,189)=313.58$ & F $(9,635)=1621.84$ \\
& Prob> F $=0.000$ & Prob> F $=0.000$ \\
& Prob> chi2 $=0.000$ & Prob> chi2 $=0.000$ \\
\hline & & \\
& & \\
& &
\end{tabular}

\section{Copyright Disclaimer}




\section{Macrothink}

Business and Economic Research

ISSN 2162-4860 2019, Vol. 9, No. 1

Copyright for this article is retained by the author(s), with first publication rights granted to the journal.

This is an open-access article distributed under the terms and conditions of the Creative Commons Attribution license (http://creativecommons.org/licenses/by/3.0/). 